\title{
Does Eurodollar Borrowing Improve the Dollar's Exchange Value?
}

\author{
DAVID H. RESLER
}

\begin{abstract}
"In a further move to improve the international position of the dollar, the Board of Governors on August 28, 1978, announced a change in reserve requirements to make it more attractive for member banks to borrow funds in the Eurodollar market. . . . The new action involves a reduction from 4 percent to zero in the reserve requirement on foreign borrowings of member banks, primarily Eurodollars, from their foreign branches and other foreign banks."
\end{abstract}

Federal Reserve BuLLETr, September 1978.

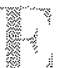
1. ARLY in 1978, the dollar began to decline sharply in value in the foreign exchange markets. This dramatic decline, shown in Chart 1 , precipitated several Federal Reserve policy actions, culminating in last November's comprehensive dollar rescue effort undertaken in cooperation with the Treasury. This action consisted of a combination of dollar-supporting efforts including an expansion of both direct foreign exchange intervention and swap arrangements, and an announced increase in the discount rate. While these actions seem to have successfully abated the dollar's decline, the desired improvement in the dollar's international position has been modest.

The action taken last November was the most dramatic of several actions taken to support the dollar. ${ }^{2}$ The quotation above identifies another such dollarnsupporting move. By removing the reserve requirements against Eurodollar borrowing, the Fed intended to encourage the use of this source of funds in order to generate a net increase in the demand for

${ }^{1}$ Federal Reserve Bulletin (September 1978 ) , p. 777 . The regulations affected by this policy action are Regulations $D$ and $M$. Regulation $D$ specifes the reserve requirements member banks must meet for various liability classifications. Regulation $M$ governs the Federal Reserve's treatment of foreign branch banks. It is important to note that the computation of the reserve requirement against "Eurodoliar borrowings" was actually on net balances due to foreign branches.

In addition to the action indicated in the quotation, the Fedwal Reserve has increased the discount rate several times during the past vear. For an assessment of the eflect of these discomut rate changes on the exchange rate, see Douglas $R$. Mudd, "Did Discount Rate Changes Affect the Foreign Exchange Value of the Dollar During 1978 ?" this Review (April $1979)$, pp. $20-26$. the dollar and thereby increase its foreign exchange value. This paper examines analytically the conditions under which removal of these reserve requirements would improve the dollar's foreign exchange value. Available data relating to Eurodollar borrowing offer little evidence that this policy intiative has fulfilled its intentions.

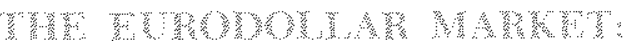

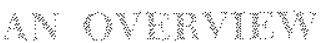

Eurodollars are simply dollar-denominated deposits placed in a bank outside the United States. Anyone may own Eurodollars and these owners may reside in a foreign country or in the United States. They may

As this article was published, the Federal Reserve announced a comprehensive change in policy that includes Eurodollar borrowing. Eurodollar borrowing will be included in the calculation of "managed liabilities." Increases in the total of these managed liabilities above a base level will be subject to an 8 percent marginal reserve requirement. This action, however, does not remove the differential reserve requirement between large CDs and Eurodollar borrowing. In fact, the new policy action may further stimulate the substitution of Eurodollars for large CDs that this paper examines. 


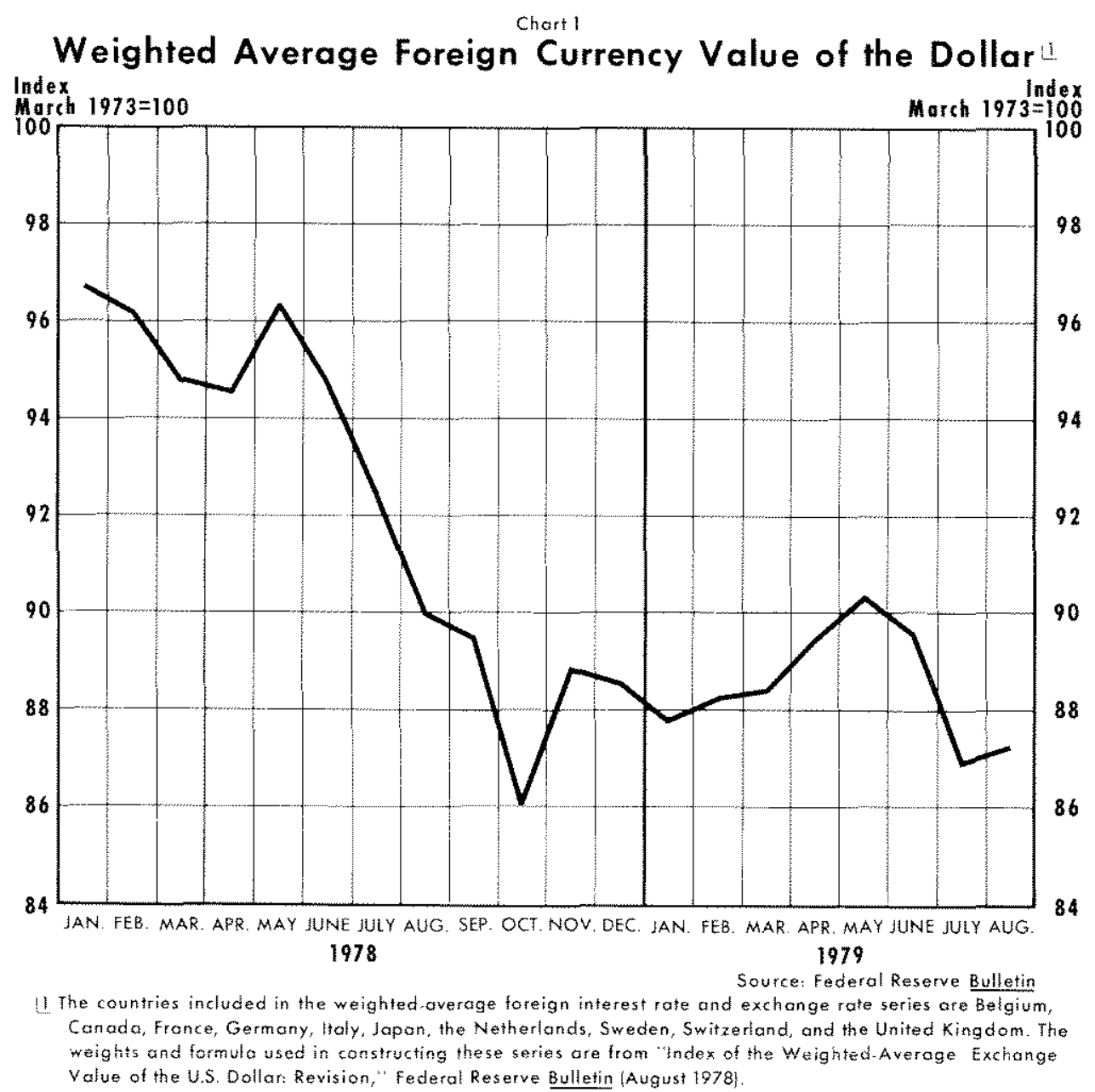

Now

be private citizens, nonfinancial corporations, other banks or financial intermediaries, or official institutions of foreign goverments.

Motives for holding Eurodollars are equally diverse. The primary motive, however, is that Eurodollars are short-term dollar-denominated assets which pay an attractive yield. Those extensively engaged in international trade view the market as espectally convenient. With a large volume of trade ultimately conducted in dollars, the Eurodollar market provides a relatively high yielding outlet for dollar balances that obviates much of the risk and transactions costs associated with converting them into a foreign asset or with investing them directly in U.S. capital markets.

Despite the "Etrodollar" designation, the market is not exclusively located in Europe. Though the largest part of the market's activity takes place in London, the rest of Europe and such diverse locations as Singapore, the Bahamas, and the Cayman Islands account for a substantial volume of Eurodollar activity.

Regardless of their location, Eurodollar banks (Eurobanks) perform an intermediary function similar to that of other banks. They issue liabilities (that is, they accept deposits) which they use to acquire earning assets, primarily loans to customers and financial investments such as bonds, commercial paper, and so on. As with other intermediaries, Eurobanks' profits are the differential between earnings received on their assets and the costs of their liabilities.

Eurodollar deposits differ from domestic U.S. bank deposits in one often overlooked but very important respect: Generally, liabilities of Eurobanks are not "checkable deposits." Eurow dollar depositors cannot. write drafts on their deposits. In other words, Eurodollars are not "money" in the same sense that demand deposits and U.S. currency are money, Eurodollars are, instead, most comparable to various "near-monies" like large denomination cer" tificates of deposit (CDs).3

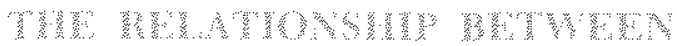

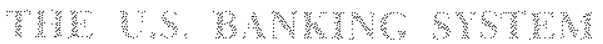

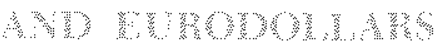

There are two important links between the Eurodollar market and the U.S. banking system. First, and most important to this discussion, many Eurodollar banks are branches or subsidiaries of U.S. commercial banks. This means that U.S. parent banks have an aux-

:ithe degree of liquidity of Eurodollars varies with the term to matirity of the deposit. The maturity of Eurodollar deposits ranges from overnight to, more typically, 30 days or more. The extent to which Eurodollars add to the world's liquid balances and thereby represent a source of world inflar tion is perhaps the most controversial aspect of the market. For a recent discussion of this problem, see Adran $W$ Throop "Eurobanking and World Inllation" Voice of the Federal Reseree Bank of Dallas (Augent 1979), pp. 8-23. 
Table 1

\begin{tabular}{|c|c|c|c|c|}
\hline & Effer & $\begin{array}{l}\text { e Cost of } \\
\text { flt } \\
\text { Eurodollar } \\
\text { Bofrowing }\end{array}$ & $\begin{array}{l}\text { Sank Liabil } \\
\text { (2) } \\
\text { Certificates } \\
\text { of Deposit }\end{array}$ & Difference \\
\hline \multirow[t]{5}{*}{1977} & August & $6,56 \%$ & $6.29 \%$ & $27 \%$ \\
\hline & September & 6.83 & 6.57 & .26 \\
\hline & Ocfober & 7,44 & 6.64 & $.80^{\circ}$ \\
\hline & Novenber & 7,39 & 7.11 & 28 \\
\hline & December & 7.42 & 715 & .27 \\
\hline \multirow[t]{12}{*}{9978} & January & 7.63 & 7.37 & 26 \\
\hline & February & 7.58 & 7.33 & .25 \\
\hline & Morch & 7.57 & 7.29 & 28 \\
\hline & April & 769 & 7,48 & 21 \\
\hline & Moy & 8.15 & 789 & 26 \\
\hline & June & 8.68 & 8.32 & 36 \\
\hline & Juky & 888 & 8.63 & 25 \\
\hline & August & 8.83 & 8.56 & 27 \\
\hline & Seplember & 912 & $9+16$ & -04 \\
\hline & October & 1012 & 10.02 & 10 \\
\hline & Novenber & 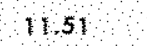 & 11.65 & -14 \\
\hline & Decenber & 1162 & 11,63 & -01 \\
\hline \multirow[t]{8}{*}{1979} & Sanuary & 1116 & 11.41 & -25 \\
\hline & February & 1079 & 1107 & -28 \\
\hline & Maref & 10,64 & 1101 & -37 \\
\hline & April & 1060 & 1092 & -32 \\
\hline & May & 10.75 & 11.03 & -28 \\
\hline & June & 10.52 & 10.82 & -30 \\
\hline & fuly. & 10.87 & 10.99 & -.12 \\
\hline & August & 11.53 & 11.62 & -.09 \\
\hline
\end{tabular}

* Calculations are hased on the reporter dafy average yied for each Eype of liability and the applicable reserve raturements.

SOUFCE: Federal Reserve Bultin and the Hexeral Feserve Bark gef Sit. Eot is

iliary source of funds for their domestic operations. Specifically, a U.S. parent bank may use the special relationship with its branch to obtain liablities (that is, to borrow from its branch) when domestic sources of funds become constrained. This occured, for example, in 1968-69 when restrictive monetary policy, coupled with Regulation Q deposit ceilings, dried up domestic sources of funds, thereby encouraging U.S. banks to utilize credit lines with their foreign branches. At other times, this relationship between parent and branch has resulted in a net flow of funds from the parent to the branch. This was, in fact, typical of the market from 1975 until early this year.

The second important link between the U.S. and Eurodollar banking systems centers on the Eurobanks' demand for reserve funds. As with any financial inter- mediary, a Eurobank maintains a stock of readily accessible funds (reserves) to meet day-to-day transactions and clearing requirements. One of the most striking and controversial features of the Eurodollar system is that, unlike domestic banks, the level of reserves held by Eurobanks is not regulated. This does not mean, however, that Eurobanks hold no reserves. Profit-maximizing considerations determine the optimal level of precautionary reserves for Eurobanks. The special characteristics of this market result in very low levels of reserves relative to total deposit volume.* Generally, Eurobanks' deposits with U.S. banks serve as precautionary reserves for the Eurodollar market.

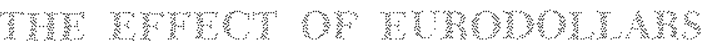

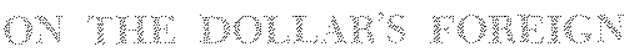

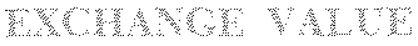

As previously noted, U.S. banks often obtain liabilities from the Eurodollar market by borrowing from their own branches or from other Eurobanks. Like other forms of foreign borrowing, this practice increases U.S. liabilities to foreigners and lowers (raises) the short-term international capital account deficit (surplus).

Falling deficits or rising surpluses generally indicate an increasing demand for dollars which in turn implies a rising value of the dollar in foreign exchange markets. ${ }^{5}$ This is the connection between Eurodollar bor. rowing and the foreign exchange rate that the August 28,1978 policy action attempted to exploit.

The connection between the net liquidity deficit and the foreign exchange rate, however, is more complicated when Eurodollars are borrowed because such borrowing need not result in a currency conversion. To see this point more clearly, consider the following example: When a U.S. resident borrows from a foreigner, he usually issues a dollar-denominated IOU.

For both a theoretical and empirical discussion of optimal Eurodollar reserves, see John $\mathrm{H}$. Makin, "Identifying a Reserve Base for the EurowDollat System," Jotmal of Finance (June 1973), pp. 609-17 and David 1 . Resler, A Study of the Euro-Dollar Market: Its Origin and Interaction with U.S. Monetary Policy, umpublished Ph.D. dissertation (The Ohio State University, $197 \%$.

5It is important to note that increased borrowing by U.S. banks tends to improve (lower) the U.S. balance of -payments deficit as measured on a net liquidity basis. It need not and probably does not, however, exert any impact on the "official settlements" balance. This balance is based only on official governmental setilements. In the case above, no intergovemmental transactions are involved. For a detailed discussion of this distmetion, see Donald S. Kemp. "Balance of Payments Concepts - What Do They Really Mean?" this Review (July 1975$),$ pp. $14+23$ 
To purchase this debt instrument, the foreigner first acquires dollars through the foreign exchange market, thereby increasing the demand for dollars. If, however, the foreigner already possesses dollar-denominated assets such as Eurodollars, the transaction does not involve the foreign exchange market even though the U.S. net liquidity deficit falls. Thus, Eurodollar borrowing need not increase the demand for dollars in the foreign exchange markets.

But, can Eurodollar borrowing produce a net increase in the demand for dollars? The answer is a qualified yes. Elimination of the reserve requirements against Eurodollar borrowing effectively reduces the cost of this source of funds. This tends to increase the total demand for Eurodollar borrowings, thereby bidding up the Eurodollar loan (and deposit) rate. If the higher relative yield on Eurodollars produces an increase in the general level of U.S. interest rates, it may induce a substitution of dollars for other curren" cies. When this occurs, the demand for dollars and the dollar exchange rate will increase. On the other hand, the higher yield on Eurodollars may induce only a substitution among dollar assets. Owners of domestic dollar CDs or U.S. Treasury bills, for instance, may switch to Eurodollars. The extent to which Eurodollars are substituted for other dollardenominated assets, then, is the key factor in evaluating the effect this policy action has on the foreign exchange value of the dollar.

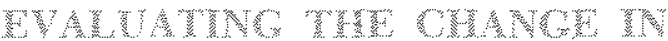

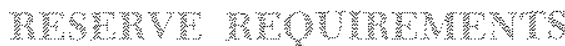

When a bank meets a reserve requirement, the cost of its funds includes both the interest expense and the earnings foregone on the idle balances (reserves) it must hold. The elimination of reserve requirements against Eurodollar borrowing lowers the effective cost of these funds to U.S. banks. ${ }^{6}$ When making portfolio decisions about their liability structure, banks compare the effective cost of funds for alternative liabilities. Thus, in assessing the relative attractiveness of Eurodollar borrowings, the effective cost of these funds must be compared with alternative liabilities.

Eurodollar borrowings can be considered a substitute for large denomination $(\$ 100,000$ or more) CDs issued by U.S. banks. The effective cost of funds for

SSpeciffcaly, the effective cost $\left(C_{j}\right)$ of any liability $(j)$ can be written as:

$$
\mathrm{C}_{1}=\mathrm{i}_{\mathrm{j}} /\left(1-\mathrm{r}_{j}\right)
$$

where $i_{j}$ and $r_{i}$ are the interest rate and required reserve ratio for the liability. these two liabilities and the differences between them over the last two years are reported in Table $1 .{ }^{7}$ While a modest cost advantage in favor of Eurodollar borrowing emerged temporarily in September 1978, a persistent cost advantage in favor of Eurodollar borrowing has prevailed only since November 1978 when the Federal Reserve increased the reserve requirement against large CDs from 6 percent to 8 percent. The cost differential fell dramatically following this action. $^{8}$

Data presented in Table 1 show that the elimination of reserve requirements against Eurodollar borrowing did little by itself to encourage a preferential shift by U.S. banks toward borrowing Eurodollars. The Fed's action of November 1, raising reserve requirements on CDs, however, appears to have eventually encouraged Eurodollar borrowing.

A persistent effective cost differential in favor of Eurodollar borrowing began to emerge in November 1978. Since U.S. banks' cost of funds had become higher in the domestic CD market than in the Eurodollar market, it is reasonable to expect that U.S. banks would have attempted to reduce their $\mathrm{CD}$ holdings relative to borrowing in the Eurodollar market.

One way for banks to replace CDs with Eurodollars without endangering well-established customer relationships is to encourage their depositors to place CDs directly with the banks' foreign branches. U.S, banks could then borrow from these branches at a lower effective cost. This transaction produces offsetting shortterm dollar flows with no net change in the demand for dollars. The Federal Reserve recognized this potential in its August 28 announcement when it ". . . reemphasized the importance of compliance by U.S. banks with its previous requests not to solicit or to

\footnotetext{
TData in column 1 of Table 1 tend to overstate the effective cost of Eurodollar borrowings. The reason is that, as noted in footmote 1 the relevant reserve requirement applies to net balances due to foreign branches. Since the aggregate net position of the banking system was negative preceding the policy revision, only a small number of banks could have been net borrowers from the market. It is only for these banks that the calculated effective cost of Eurodollar funds is appropriate.

$8 \mathrm{~A}$ brief digression on the characteristics of this cost differential should prove illuminating. In constructing Table 1 , the Emrodollar borrowing rate is the three-month interbank loan rate as published by the Federal Reserve. This reported rate represents the Eurobank's opportunity cost of lending to a U.S. (j.e., its parent) bank. A U.S. bank may be willing to borrow from its Eurobank branch even when the cost differential favors the CD market. This may occur if earnings and costs of the parent and branch are differentially treated under the relevant tax laws for the two banks. Thus, even a small positive cost differential may be consistent with a domestio bank's preference for Earodollar borrowing.
} 
Table 2

\section{Large $C D_{s}$ and Eurodollar Deposits of U.S. Residents \\ (Billions of Dollars, Not Sersonally Adjusted)}

\begin{tabular}{|c|c|c|}
\hline$\because \quad:$ & $\begin{array}{c}\text { large } \\
\text { Denomination } \\
C_{s}\end{array}$ & $\begin{array}{l}\text { U.S. Nonbanks" } \\
\text { Eurodollor Deposts } \\
\text { af Foreign Banthes } \\
\text { of U.S Banks }\end{array}$ \\
\hline 1978 January & $\$ 76.4$ & NA. \\
\hline February & 76.9 & N.A. \\
\hline March & 80.2 & $N_{A}$ \\
\hline April & 81.4 & $N A$ \\
\hline May & 846 & $\$ 20.1$ \\
\hline Sune & 863 & 216 \\
\hline fufy & 87,3 & 230 \\
\hline August & 880 & 248 \\
\hline Seplember & 90,3 & 218 \\
\hline October & 90.8 & 247 \\
\hline November & 964 & 259 \\
\hline December & 995 & 250 \\
\hline 70 Jonuary & 1011 & 30.5 \\
\hline February & 99.6 & 31,5 \\
\hline Morth & 975 & 330 \\
\hline Apri: & 92.6 & 305 \\
\hline May & 889 & 348 \\
\hline Iune & 84.4 & 35.3 \\
\hline foly & 840 & $N A$ \\
\hline August & 864 & $N A$ \\
\hline Seplember: & 89.8 & $N A$ \\
\hline
\end{tabular}

Sounce: Federal Reserve Bthletin and Boatd of Governors of the Federal Reserwe System.

encourage deposits by U.S. residents at their foreign branches..."

Data suggest that very little of this direct transfer has occurred (Table 2, column 2). Eurodollar deposits of U.S. nonbank residents have increased steadily since May 1978 but have shown no dramatically sharper rise when large CDs have fallen. These data, however, probably understate the value of CDs that U.S. residents have replaced with Eurodollar deposits. Instead of transferring deposits to branches of U.S. banks, U.S. residents may have established Eurodollar accounts with foreign banks. These banks conld then sell Eurodollar CDs in a secondary market to U.S. foreign branches. The net effect of these transactions is the same as when U.S. residents deposit funds directly with the branches. The important difference, however, is that the transactions outlined here would not pro-

Federal Reserve Bulletin (September 1978), p. 778. duce any changes in the foreign branches' liabilities to U.S. nonbanks.

Any empirical assessment of Eurodollar borrowing by U.S. banks must begin with a word of caution: Since Eurodollar borrowings are not directly reported by U.S. banks, available data provide only approximations of the actual borrowing volume.

In October of this year, the Federal Reserve Board initiated reporting of new data that provide useful approximations for Eurodollar borrowing. ${ }^{10}$ These data record net balances due to directly related for. eign institutions. The data measure the net direction of the flow of funds between the U.S. banking system and the Eurodollar market. Eurodollar borrowing by U.S. banks represents only part of the net flow of funds and may be offset by loans from U.S. banks to Eurobanks. Nevertheless, changes in net balances due to directly related foreign institutions represent a reasonable proxy for changes in Eurodollar borrowing. For instance, an increase of $\$ 1$ billion in the "net balances" is interpreted as an increase in Eurodollar borrowing of $\$ 1$ billion. Data for this measure of Eurom dollar borrowing are given in Table 3 .

Data reported in Table 3 reveal that Eurodollar borrowing by U.S. banks changed very little in the four months immediately following the change in reserve requirements. At the same time, the data indicate that Eurodollar borrowing has increased sharply since January 1979. Column 1 shows that, in January 1979, the net flow of dollars from U.S. banks to their own branches began to reverse itself. The net outlow fell substantially each month and finally became a net inflow from Eurobanks in May 1979. This flow reversal is attributable to the extensive Eurodollar borrowing by U.S. banks. The data reveal that U.S. banks have increased their Eurodollar borrowing from their own branches by $\$ 1.9$ billion since the beginning of the year. Over the same period, total net balances due to related foreign institutions increased by more than $\$ 26$ billion. Both data are essentially consistent with the incentive pattern reported in Table 1 . The data suggest that the increase in Eurodollar borrowing this year can be attributed less to the Fed's elimination of reserve requirements against Eurodollar borrowing than to the Fed's increase in reserve requirements against large CDs.

foth the past, most researchers measured borrowing with gross claims (in dollars) of foreign branch banks on their parent U.S. bank. This measured only Eurodollar borrowings from their own branches but did not record borrowing from other Eurobanks nor did it account for borrowing by nonmember U.S. banks. Nevertheless, these data were the only useful proxies for Eurodollar borrowing. 


\section{H. BA.

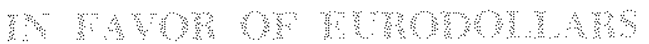

The overall success of the August policy action in terms of its effect on the dollar's exchange value depends on whether this Eurodollar borrowing is substituted for more conventional liabilities, such as large denomination CDs. If this has occurred, there is little reason to believe that the increased borrowing by U.S. banks has produced a net increase in the demand for dollars in foreign exchange markets. To evaluate the extent of this liability substitution ("round-tripping"), the behavior of large CDs over this period must be examined. Data on this liability (Table 2) reveal a substantial reduction in the total amount of CDs outstanding since the beginning of the year. From the January peak of $\$ 101.1$ billion, CDs fell to $\$ 84.0$ billion in July, a drop which accompanies the emergence of a relative cost disadvantage for CDs (reported in Table 1). It is interesting to note that, as CDs fell by about $\$ 17$ billion from January to July, liabilities of U.S. banks to their foreign branches rose by $\$ 17.4$ billion. The general pattern in this data suggests an apparent switching of Eurodollars and large CDs. ${ }^{11}$

In August and September, data on the volume of CDs and preliminary data on Eurodollar borrowing both show an increase in response to strong U.S. credit demands. This suggests that, since the cost advantage in favor of Eurodollar borrowing has now virtually disappeared, both liabilities will grow in response to overall credit demand.

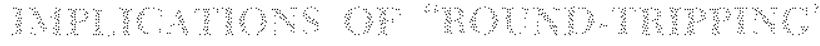

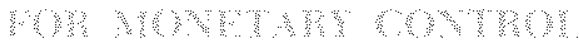

So far, the discussion has ignored any effect this substitution of Eurodollar borrowing for domestic CDs may have on the U.S. money supply. Since the primary advantage to U.S. banks from borrowing Eurodollars is that these liabilities are not subject to reserve requirements, the substitution of Eurodollar borrowing for CDs "liberates" reserves. For example, suppose a U.S. bank allows its CDs to decline by $\$ 1$ million and offsets this out tlow by borrowing $\$ 1 \mathrm{mil}$ lion from its foreign branch. The bank's total liability position is unchanged by the transaction. The bank's asset side, however, shows that the transaction has

\footnotetext{
11The data on Eurodollar borrowing is not sufficiently accurate to warrant the conclusion that this switchover has been complete, since it sems inappropriate to argue that only Eurodollars have replaced CDs. More extensive use by domestic money managers of other short-tem financial instrum ments including tepurchase agreements and commercial paper has probably also diminished their use of CDs.
}

Table 3

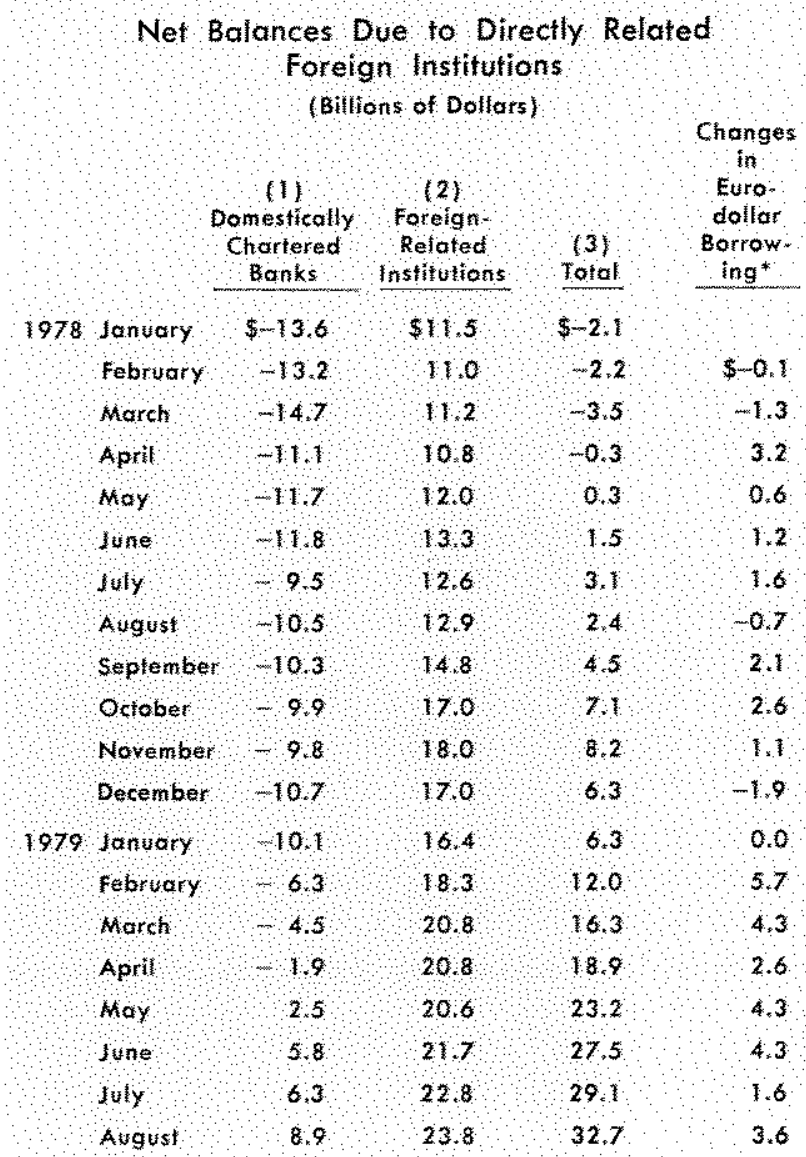

Equals Changes in Column 3 .

SoURCE Federal Reserve Bulletin and the Bonde of Governors of the Federal Reserve Systen:

generated an additional $\$ .08$ million in excess reserves which it can then lend. Lending these newly generated excess reserves increases the U.S. money supply unless the increase in excess reserves is offset by Federal Reserve open market operations.

Of course, such an increase in the money supply could prove counterproductive to the Fed's objective of improving the dollar's foreign exchange value. If the faster growth of money leads to a higher expected rate of inflation in the United States and, hence, lowers the value of the dollar in the future, the dollar's current foreign exchange value will also fall as speculators attempt to minimize the anticipated exchange rate loss.

Unless Federal Reserve open market operations offset this increase in reserves, there will be a multiple expansion of the money supply equal to the money multiplier times the newly liberated reserves. Under this assumption, the reduction in CDs of $\$ 17$ billion 
from January to July (if offset by an equal increase in Eurodollar borrowing) would have resulted in about a $\$ 3.4$ billion increase in M1. ${ }^{12}$ This amounts to roughly 40 percent of the increase in M1 (not seasonally adjusted) that occurred from January to July 1979 , and suggests that increases in Eurodollar borrowing have contributed to a more rapid expansion of the money supply. Since foreign exchange rates are sensitive to differential rates of anticipated inflation (and, hence, money growth), Eurodollar borrowing of this magnitude would indeed have affected the dollar's exchange value, but in a direction opposite to that intended by the Federal Reserve Board.

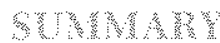

By raising the reserve requirement on large CDs after eliminating the reserve requirement for Eurodollar borrowings, the Federal Reserve induced U.S. banks to borrow from their foreign branches. The combination of these two policy changes contributed to a rapid expansion in Eurodollar borrowing. These policies would have to be judged a success were their

12This calculation assumes a constant money multiplier of 2.5 . sole intent to increase Eurodollar borrowing. While the elimination of reserve requirements against Eurodollars should increase demand for Eurodollars, it need not increase the demand for dollars in the foreign exchange market. However, the stated objective was to encourage Eurodollar borrowing which, in tum, would increase the foreign exchange value of the dollar. The link between Eurodollar borrowing and the foreign exchange value of the dollar, however, is more tenuous than that implicit in the Fed's actions.

Though the data do not permit a definitive analysis, available evidence suggests that a by-product of these policy actions has been the substitution of Eurodollar borrowing for CDs. This kind of substitution does not involve foreign exchange transactions and therefore has little direct effect on the dollar's exchange value.

There may, however, be an indirect effect on the foreign exchange value of the dollar. Substitution of reserve-free Eurodollar borrowing for reservable CDs has the potential to increase the U.S. money supply. Unless Federal Reserve open-market operations offset the increase in reserves that this substitution produces, the more rapid growth of money that results may actually depress the dollar's foreign exchange value. 